\section{Tverrfaglig musikalsk forståelsesmodell}

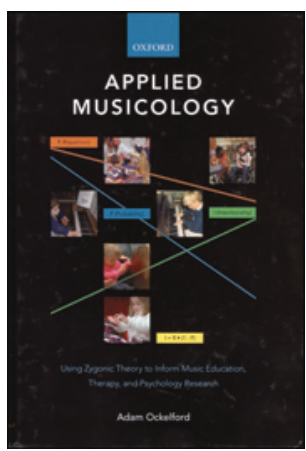

\section{Adam Ockelford Applied musicology}

Using zygonic theory to inform music education, therapy, and psychology research. $510 \mathrm{~s}$, tab, ill. Oxford: Oxford University Press, 2012. Pris GBP 50 ISBN 978-0-19-960763-1

Gjennom de siste tiårene har det vært en voksende interesse for musikk som støttetiltak i pedagogikk, psykologi, psykisk helsevern og ulike områder av medisin, eksempelvis i pediatri og geriatri. Likevel hersker det uklarhet rundt hva «musikk som tiltak» er. Psykologisk forskning har gitt innblikk i persepsjon av musikk, og innflytelsesrike forskere som Tia DeNora har gitt rike innblikk i musikkens sosiale funksjon fra en sosiologisk synsvinkel. Likevel har et «felles språk» for å kunne fremme dialogen rundt musikkens applikasjonsområder manglet.

Adam Ockelford er professor i musikk og leder The Applied Music Research Centre ved University of Roehampton i London. I sin tidlige karriere arbeidet han i psykisk helsevern og så hvordan barn med store utviklingsforstyrrelser var i stand til å delta i musikkaktiviteter som skulle ligge langt over deres funksjonsnivå. På grunnlag av disse erfaringene utviklet han «zygonic theory», som i boken eksemplifiseres med en rekke musikalske snutter som illustrerer hvordan musikk berører intensjonalitet og interaksjon, og hvordan musikalske sekvenser kan vekke svekkede funksjoner. Slik bygger Ockelford opp det han kaller «applied musicology» som et samlebegrep som kan vise vei til en ekte tverrfaglighet basert på musikk som fenomen.

Forfatteren går grundig til verks. Styrken i hans fremstilling er de mange musikalske eksemplene, som gjør at resonnementene i den teoritunge boken ikke blir hengende i luften. Likevel blir fremstillingen ufullstendig når målet er såpass ambisiøst og vidtfavnende som her: «Forskningen på hvordan musikk påvirker hjerne og nervesystem har gitt helt nye muligheter til å bygge en tverrfaglig forståelse av hvordan musikk kan få en ny rolle som forståelsesmodell for nye tiltak innen en rekke fagfelt som medisin, psykologi, psykisk helsevern og pedagogikk.»

Jeg mener at det svekker bokens intensjon at noen av de største forskningsområdene blir utelatt i forfatterens grundige presentasjon. Ockelford vil særlig nå dem som arbeider innen musikkopplæring, musikkpsykologi og pedagogikk, men jeg tror at hans dypdykk ville hatt større gjennomslagskraft hvis han hadde inkludert den utstrakte forskningen og empirien som allerede har skapt en ny tverrfaglig forståelse av musikkens potensial utenfor konsertsalen. Eksempelvis ville en gjennomgang av Manfred Clynes' banebrytende forskning rundt sammenhengen mellom musikalske, emosjonelle og nevrologiske forløp belyst forfatterens ærend, slik jeg ser det. Boken vil først og fremst være for spesialiserte forskere innen musikkutdanning.

\section{Audun Myskja}

Senter for livshjelp

Sk

\section{Dokumentarisk teater som berører}

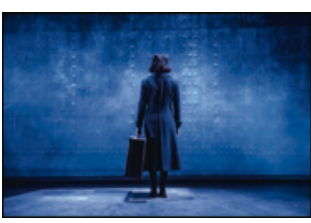

Otto Homlung

Tvillingsjeler - Gunvor Hofmo og Ruth Maier

Skuespill basert på Jan Erik Volds

dokumentariske bøker. $90 \mathrm{~min}$

Riksteateret (Turné: 5.3.-6.5.2013).

Billettpris NOK 290

Riksteateret hadde nylig urpremiere på Otto Homlungs teaterstykke. Tvillingsjeler - Gunvor Hofmo og Ruth Maier. Stykket handler om den jødisk-østerrikske kvinnen Ruth Maier. Hun kom til Norge 22 år gammel i 1939 og bodde her uten egen familie eller slekt, til hun sammen med de andre jødene ble sendt til Auschwitz i 1942. Senhøstes 1940 ble hun kjent med en ung kvinne, Gunvor Hofmo (1921-1995), som ennå ikke hadde debutert som lyriker. De ble venner, svært gode venner, men etter hvert oppfattet Ruth Gunvor som et lite barn som måtte tas hånd om. Hun forsto også at de to ikke kunne ha noe varig forhold, dertil var Gunvor for ustabil.

Hva Ruth ikke visste, var at Gunvor allerede på denne tiden var i prodromalfasen til sin paranoide schizofreni som ble manifest (og kronisk) i 1947. Hva Gunvor kanskje ikke forsto, var hvor isolert og ensom Ruth Maier var, og hvorfor hun ikke benyttet muligheten til å rømme til Sverige da jødedeportasjonene begynte, men valgte å følge jødene i døden. Tapet av Ruth ble senere ett av temaene i de fleste av Gunvors 20 diktsamlinger.

Regissør Otto Homlung har gjort stykket til en ganske dokumentarisk fortelling om Gunvor Hofmos og Ruth Maiers liv. Teksten er basert på Ruth Maiers fyldige dagbøker og på Gunvor Hofmos enestående dikt. Scenisk befinner vi oss i korridoren på Gaustad, der Gunvor Hofmo skrev mange av sine diktsamlinger. I det samme rommet utspilles scener mellom Gunvor og Ruth i ungdommen. Den aldrende Gunvor gir noen kommentarer til deres forhold etter hvert som det utvikler seg. Men først og fremst leser hun noen av sine mest kjente og gripende dikt der disse passer inn i det som skjer mellom de to, eventuelt henvendt til de to. Scenebildet er ellers preget av talende videobilder som kunne vært malt av Ruth.

Marit Østby gestalter den eldre Hofmo på en svært autentisk måte. En del av de utvalgte diktene er skrevet som klagesanger, men leses med en stoisk ro som griper. Disse diktene alene bærer nesten hele forestillingen og gjør den verd å besøke. Silje Storstein er den unge Gunvor som varsomt, men litt for «flagrende», nærmer seg Ruth. Hennes emosjonelle tyngde og depressivitet ser vi lite til. Ambivalensen hennes i forholdet til Ruth er nok der, men den kommer likevel som en altfor stor overraskelse når hun i sluttscenen plutselig trekker seg helt.

En liknende svakhet er det ved Janne Helbergs noe endimensjonale utforming av Ruth. Hennes fortvilelse over å ha mistet alle sine kjære, hennes mangel på trygg tilknytning i Norge og henne ressurser som kunstner kommer ikke tydelig frem. Vi ser henne bare som en morsom, glad og lettvint ungpike, og det er vanskelig å forstå hvorfor hun gir opp Gunvor og holder på sin tilknytning til jødene, selv om det betyr å dø sammen med dem.

Selv om stykket altså har noen svakheter i rolleutformingen av de unge kvinnene, er historien om Gunvor og Ruth fortalt på en sannferdig, engasjerende og til dels gripende måte. Her møter vi samtidig Gunvor Hofmos ekspresjonistiske forfatterskap og liv med en alvorlig psykose og et livlig, men desperat forsøk på å etablere en nær relasjon hos to skadeskutte tvillingsjeler. Konteksten er Holocaust med sine redselsfulle konsekvenser.

Ta med deg din partner og dine eldre barn og ungdommer. Dette er både en viktig historietime og et møte med Gunvor Hofmos poetiske univers.

Per Vaglum

Avdeling for medisinsk atferdsvitenskap

Universitetet i Oslo 